\title{
Retraction Note to: “Hassan W, David J (2014) Effect of lead pollution on soil microbiological index under spinach (Spinacia oleracea L.) cultivation. J Soils Sediments 14: 44-59
}

\author{
Waseem Hassan $^{1}$ • Julie David ${ }^{2}$
}

Published online: 14 March 2019

(C) Springer-Verlag GmbH Germany, part of Springer Nature 2019

Retraction Note: Journal of Soils and Sediments (2014) 14:44-59

https://doi.org/10.1007/s11368-013-0802-3

Published Online 13 November 2013

This article has been retracted by the Editors-in-Chief. After a thorough investigation carried out by the Higher Education Commission of Pakistan and Muhammad Nawaz Sharif University of Agriculture, Pakistan, it was found that one of the co-authors, Mr. Waseem Hassan, plagiarized sections of this article from Mr. Idrees Haider's masters' thesis that was published in 2009 at PMAS Arid Agriculture University, Rawalpindi, Pakistan. A comment regarding this situation was also published by the editors-in-chief to alert readers in May 2014 in the Journals of Soils and Sediments (Volume 14, Issue 5, pp. 1021-1021).

Given the uncertainty regarding the origin of the data, its analysis and research methodology, the Journal of Soils and Sediments article in question is being retracted.

Publisher's note Springer Nature remains neutral with regard to jurisdictional claims in published maps and institutional affiliations.

The online version of the original article can be found at https://doi.org/ 10.1007/s11368-013-0802-3

Waseem Hassan

wasagr@yahoo.com

1 Huazhong Agriculture University, Wuhan 430070, China

2 Fachbereich Biologie, Freie Universität, 14195 Berlin, Germany 